\title{
Ciliated protozoan communities over Cobb Seamount: increase in biomass and spatial patchiness
}

\author{
Télesphore Sime-Ngando ${ }^{1}$, Kim Juniper $^{1, *}$, Alain Vézina ${ }^{2}$ \\ ${ }^{1}$ Centre Océanographique de Rimouski, Département d'Océanographie, 310 allée des Ursulines, Rimouski, Québec, \\ Canada G5L 3A1 \\ 2 Institut Maurice-Lamontagne, Ministère des Pêches et Océans Canada, 850 Route de la mer, C.P. 1000, Mont-Joli, Québec, \\ Canada G5H $3 \mathrm{Z4}$
}

\begin{abstract}
Species composition, abundance, biomass and patchiness of ciliated protozoa were examined for evidence of increasing standing stock in relation to productivity (chlorophyll $a$, primary production) over an eastern subarctic Pacific seamount (Cobb, $46^{\circ} 45^{\prime} \mathrm{N}, 130^{\circ} 48^{\prime} \mathrm{W}$ ). Ciliates were unusually diverse with 49 different taxa recorded ranging in size from 15 to $350 \mu \mathrm{m}$ in length. Their abundance was relatively low while carbon biomass was very high compared to those of most marine systems. This implies that over Cobb Seamount, ciliates counterbalance their low numbers by increasing in size, partly due to exclusion of small planktonic common species (Strobilidium spp., scuticociliates, hymenostome-type cells) by larger cells, particularly plastidic oligotrichs of the genus Laboea. Integrated biomass to $80 \mathrm{~m}$ depth at times peaked at $0.6 \mathrm{~g} \mathrm{C} \mathrm{m}^{-2}$, which exceeds the standing stock of the entire microzooplankton in some oceanic areas. Statistical 2-dimensional analysis of the spatial structure showed the existence of patchiness. Meso-scale and circular patches (about $6 \mathrm{~km}$ or more in diameter, horizontally) were probably related to seamount-induced physical forcing which likely generates microhabitats favorable to the growth of opportunistic or physiologically adapted populations. Direct observations showed that ciliates were a major component of the microzooplankton over the seamount.
\end{abstract}

\section{INTRODUCTION}

There are more than 30000 seamounts in the Pacific Ocean greater than $1000 \mathrm{~m}$ in height (Smith \& Jordan 1988). Considering their abundance and the singular conditions created by their interaction with ocean flow, these topographic features have received little attention, particularly with respect to their biology. Effects of large amplitude elevations of bottom topography on local and regional circulation patterns are often complex and varied (Roden 1987). In the near-surface layer, these effects include deflection or modification of flow regimes (Roden \& Taft 1985, Vastano et al. 1985, Joyce 1987), suppression of eddy activity (Bernstein \& White 1977), modification of internal wave trains (Kaneko et

\footnotetext{
- Present address: Département des Sciences Biologiques, Université du Québec à Montréal, C.P. 8888, Succ. A, Montréal, Québec, Canada H3C 3P8
}

al. 1986) and creation of eddies, rings (Patzert 1969 , Huppert \& Bryan 1976, Royer 1978, Cheney et al. 1980) and currents (Mysak \& Magaard 1983, White \& Walker 1985).

The physical perturbations created by seamounts have been proposed to directly enhance productivity (Boehlert \& Genin 1987). Local increases of chlorophyll have been reported around some seamounts (Genin \& Boehlert 1985, Lopukhin 1986, Dower et al. 1992), and there is some evidence of enrichment of biological resources at higher trophic levels. High abundances of demersal fishes have been observed over seamounts (Uchida \& Tagami 1984) and relatively high concentrations of sessile suspension feeding organisms have been related to localized increases in current speeds (Grigg et al. 1987). The food supply for oceanic benthic communities originates in surface waters, through either sinking of photosynthetic carbon as intact cells (Lampitt 1985) or 
via a series of trophic transformations (Fowler \& Knauer 1986). After an initial observation of enhanced phytoplankton biomass over Cobb Seamount and an anticyclonic deflection of oceanic flow consistent with a theoretical stratified Taylor cone (Dower et al. 1992), we undertook a multidisciplinary investigation of physical and biological processes in surface waters at this site. We were particularly interested in the effects of seamount-related physical perturbations on trophic links between phytoplankton and heterotrophic microorganisms. Here we report on species composition, abundance, biomass, and spatial distribution of planktonic ciliates in the euphotic zone of Cobb Seamount and their relationship to chlorophyll a (chl a) concentration and primary productivity.

Biologists have rarely had the opportunity to investigate microzooplankton communities over seamounts. These organisms, especially ciliated protozoa, are now recognized as important components of aquatic ecosystems (Porter et al. 1979, Sherr \& Sherr 1984). Their importance as trophic links is further enhanced in the eastern subarctic Pacific where they were hypothesized to be the major herbivorous grazers (e.g. Frost 1987). This hypothesis was recently verified and confirmed by Strom (1990).

\section{METHODS}

Cobb Seamount $\left(46^{\circ} 45^{\prime} \mathrm{N}, 130^{\circ} 48^{\prime} \mathrm{W}\right)$ is located $500 \mathrm{~km}$ off the west coast of Canada (Fig. 1), near the southeastern limit of the oceanic region known as the subarctic Pacific. The surrounding waters are associated with the upwelling domain of the eastern North Pacific, and characterized by higher total chlorophyll and spatial heterogeneity, compared to the western North Pacific (delimited by the Emperor Seamount Chain) where waters are oligotrophic with low spatial heterogeneity (e.g. Venrick 1979, 1991). Cobb differs from other seamounts in that its summit penetrates well into the euphotic zone (Dower et al. 1992), rising from a $2800 \mathrm{~m}$ abyssal plain to $24 \mathrm{~m}$ depth (Fig. 1).

Field work was undertaken during the first week of August 1991. Sampling stations were organised along 6 spokes originating at the seamount summit (Fig. 1, Table 1). At each station, vertical profiles were taken with a rosette sampler fitted with a Guildline digital CTD, a Seatech transmissometer and a fluorometer. One spoke was visited per day from the periphery to the summit zone, between first light and midday. At selected survey stations, GoFlo bottle casts were taken, usually at $10,15,25,30,50$ and $80 \mathrm{~m}$ depths, for chl $a$, primary production, ciliates and other measurements. Bottle cast stations were positioned to correspond to major topographic features of the seamount and to

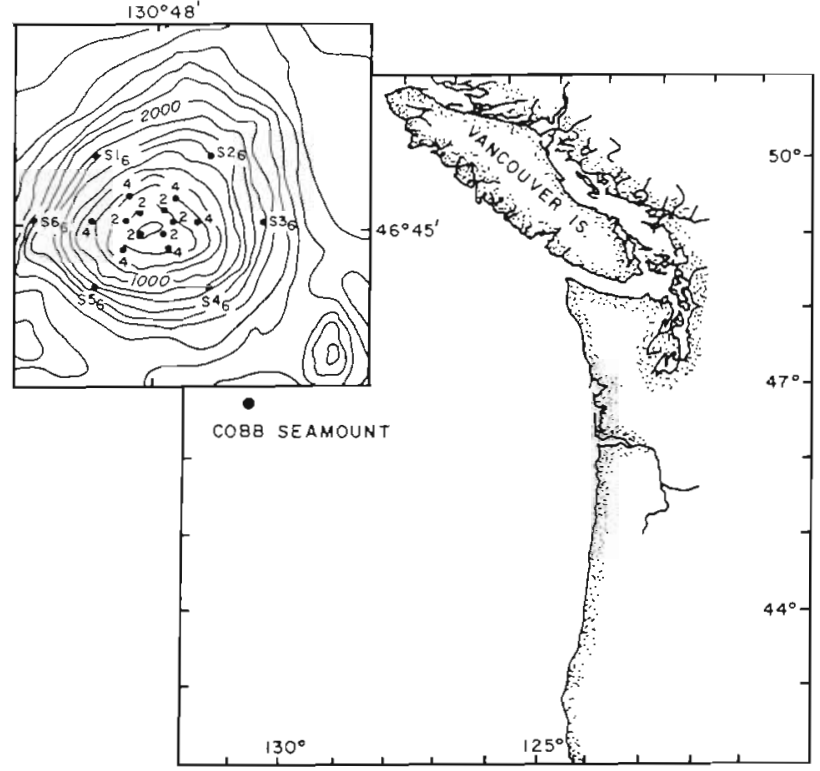

Fig. 1. Location of Cobb Seamount off the west coast of North America. Inset shows the topography of Cobb Seamount (contour interval $200 \mathrm{~m}$ ) and the sampling stations organised along 6 spokes (S) originating at the seamount summit. Each spoke contained 3 stations $(2,4,6$; cf. Table 1$)$ from the summit zone to the periphery

Table 1. Coordinates of sampling sites (cf. Fig. 1) around Cobb Seamount. Sx.y: Spoke $x$, site $y$

\begin{tabular}{|c|c|}
\hline Sites & Location \\
\hline S1.2 & $46^{\circ} 47^{\prime} \mathrm{N}, 130^{\circ} 50^{\prime} \mathrm{W}$ \\
S1.4 & $46^{\circ} 49^{\prime} \mathrm{N}, 130^{\circ} 51^{\prime} \mathrm{W}$ \\
S1.6 & $46^{\circ} 54^{\prime} \mathrm{N}, 130^{\circ} 55^{\prime} \mathrm{W}$ \\
S2.2 & $46^{\circ} 47^{\prime} \mathrm{N}, 130^{\circ} 47^{\prime} \mathrm{W}$ \\
S2.4 & $46^{\circ} 49^{\prime} \mathrm{N}, 130^{\circ} 46^{\prime} \mathrm{W}$ \\
S2.6 & $46^{\circ} 54^{\prime} \mathrm{N}, 130^{\circ} 41^{\prime} \mathrm{W}$ \\
S3.2 & $46^{\circ} 45^{\prime} \mathrm{N}, 130^{\circ} 46^{\prime} \mathrm{W}$ \\
S3.4 & $46^{\circ} 45^{\prime} \mathrm{N}, 130^{\circ} 43^{\prime} \mathrm{W}$ \\
S3.6 & $46^{\circ} 45^{\prime} \mathrm{N}, 130^{\circ} 34^{\prime} \mathrm{W}$ \\
S4.2 & $46^{\circ} 43^{\prime} \mathrm{N}, 130^{\circ} 47^{\prime} \mathrm{W}$ \\
S4.4 & $46^{\circ} 42^{\prime} \mathrm{N}, 130^{\circ} 46^{\prime} \mathrm{W}$ \\
S4.6 & $46^{\circ} 37^{\prime} \mathrm{N}, 130^{\circ} 41^{\prime} \mathrm{W}$ \\
S5.2 & $46^{\circ} 43^{\prime} \mathrm{N}, 130^{\circ} 50^{\prime} \mathrm{W}$ \\
S5.4 & $46^{\circ} 42^{\prime} \mathrm{N}, 130^{\circ} 51^{\prime} \mathrm{W}$ \\
S5.6 & $46^{\circ} 37^{\prime} \mathrm{N}, 130^{\circ} 55^{\prime} \mathrm{W}$ \\
S6.2 & $46^{\circ} 45^{\prime} \mathrm{N}, 130^{\circ} 51^{\prime} \mathrm{W}$ \\
S6.4 & $46^{\circ} 45^{\prime} \mathrm{N}, 130^{\circ} 54^{\prime} \mathrm{W}$ \\
S6.6 & $46^{\circ} 45^{\prime} \mathrm{N}, 131^{\circ} 03^{\prime} \mathrm{W}$ \\
OFFSMT & $47^{\circ} 10^{\prime} \mathrm{N}, 130^{\circ} 48^{\prime} \mathrm{W}$ \\
QED & $49^{\circ} 60^{\prime} \mathrm{N}, 138^{\circ} 38^{\prime} \mathrm{W}$ \\
\hline
\end{tabular}

include sites away from the immediate influence of the seamount. One additional bottle cast was taken on the summit and 2 others at 2 different stations, situated away from the direct influence of Cobb (Table 1). We 
called the latter Stns OFFSMT $\left(47^{\circ} \mathrm{N}, 130^{\circ} \mathrm{W}\right)$ and QED $\left(50^{\circ} \mathrm{N}, 138^{\circ} \mathrm{W}\right)$. Stn QED is situated in the Alaska gyre, in a different oceanographic regime.

On board ship, the GoFlo bottles from each depth were immediately subsampled for chl a and primary productivity determinations and for examination of ciliates. Chlorophyll concentration was determined fluorometrically (Yentsch \& Menzel 1963, HolmHansen et al. 1965). Particles from $100 \mathrm{ml}$ samples were retained on $\mathrm{GF} / \mathrm{F}$ filters and extracted in $90 \%$ acetone in the dark and under refrigeration for 24 to $72 \mathrm{~h}$. The errors involved in this procedure are small (Venrick et al. 1987).

Primary production was measured by SteemannNielsen's (Venrick 1991) ${ }^{14} \mathrm{C}$ method, from the subsamples collected before local apparent noon. Subsamples $(250 \mathrm{ml})$ from each of the 6 depths were drawn into 2 transparent and 1 opaque (control) polycarbonate bottles. Each was inoculated with $15 \mu \mathrm{Ci}{ }^{14} \mathrm{C}$ and incubated on deck in surface seawater cooled tubes fitted with neutral density filters to simulate light intensity at the depths of origin, usually at $50,25,10,6,1$ and $0.1 \%$ of surface light. Subsequently, samples were incubated for $4 \mathrm{~h}$ at mid-day, then filtered, acidified and stored in scintillation cocktail until counting of radioactivity. Primary production was not measured at Sites S4.4, S5.4 and S6.4.

To preserve ciliates, $200 \mathrm{ml}$ samples were fixed with mercuric chloride (final concentration $2.5 \% \mathrm{v} / \mathrm{v}$ ) and stained with a drop of $0.04 \% \mathrm{v} / \mathrm{v}$ bromophenol blue (Pace \& Orcutt 1981, Sime-Ngando et al. 1990). Ciliates were counted by Utermöhl's inverted microscope method (Sime-Ngando et al. 1990) following sedimentation of 100 to $200 \mathrm{ml}$ subsamples for $24 \mathrm{~h}$. All samples were counted within $4 \mathrm{mo}$, because of significant loss occurring during longer storage (Sime-Ngando \& Grolière 1991). At least 200 cells of each representative taxon were counted in 1 or, if necessary, several subsamples, except in a few of the deepest samples. Ciliate biomasses were calculated from the mean cell volume of each taxon (see Table 2) which was determined by measuring cell dimension with a micrometer and approximating the cell shapes to geometrical figures. The carbon biomass was then estimated according to Putt \& Stoecker (1989), assuming that $1 \mu \mathrm{m}^{3}=0.19 \mathrm{pgC}$.

Naked ciliates were identified either in vivo (e.g. Sime-Ngando et al. 1990, Sime-Ngando \& Hartmann 1991) under stereoscopic and phase-contrast microscope, or by various cytological techniques, according to Dragesco \& Dragesco-Kerneis (1986). The infraciliature (kinetid) of common species was observed by protargol staining after Bodian (1937), as modified by Tuffrau (1967) and Grolière (1980). This technique also reveals the nuclear apparatus and the excretory pore of the contractile vacuole. Tintinnids were identified, under phase-contrast microscope, from lorica shape and dimensions, according to Marshall (1969).

The spatial distribution of ciliates, chlorophyll and primary productivity was examined by 2 -dimensional spatial autocorrelation analysis (Cliff \& Ord 1973, 1981, Sokal \& Oden 1978, Legendre \& Legendre 1984), using Moran's (1950) I and Geary's (1954) c. The null hypothesis was as follows: there was no difference between sampling sites at the survey stations. The coefficient $I$ is somewhat similar to Pearson's coefficient of linear correlation. For a distance class $D$, the test measures the randomness of the spatial distribution of the studied variable. The coefficient $c$ has a similar function but with an inverted scale compared to $I$. The results are presented as correlograms where $I$ and $c$ are plotted as a function of distance classes obtained from a matrix of geographic distances $(\mathrm{km})$, computed from the coordinates of the sampling points. In a correlogram, 1 value is computed for all pairs of points located within each chosen distance class; the values computed for all classes are assembled in the correlogram. Each value can be tested for significance (Cliff \& Ord 1973, 1981, Sokal \& Oden 1978, Legendre \& Legendre 1984). When a value exceeds the critical value (positive or negative), the hypothesis of a random spatial distribution between sites (i.e. no spatial autocorrelation) is rejected at the specified level of significance. An overall examination of the significant values in a correlogram makes it possible to formulate statements about the underlying spatial structure (Sokal 1979). Finally, the Box-Cox method (Sokal \& Rohlf 1981) was used to approximate the best normalizing transformation of all variables. As confirmed by the Kolmogorov-Smirnov test of normality (Lilliefors 1967), the $y=\log _{e}(x+1)$ transformation was found to normalize all our variables and thus was used during statistical analysis. Computations were carried out with the AUTOCOR program included in the ' $R$ package for multivariate data analysis' written and distributed by A. Vaudor and P. Legendre respectively (e.g. Legendre \& Troussellier 1988).

\section{RESULTS}

\section{Physical environment (temperature and salinity)}

During our cruise, the area was characterized by a salinity and temperature front that ran in a general NW-SE direction, skirting the western flank of the seamount. The front is particularly well marked on plots of temperature at the sigma-t $=25.4$ isopycnal, which was situated (Fig. 2A) at the top of the permanent halocline (between 80 and $90 \mathrm{~m}$ ). At the surface, the salinity of the mixed-layer displays smaller scale structures: a salinity minimum just north of the summit 
and a salinity maximum south of the summit (Fig. 2C). The physical data assembled to date suggests that the salinity minimum is diagnostic of a localized region of cyclonic internal wave activity and intense mixing, probably associated with a bottom-trapped Taylor column (Dower et al. 1992, H. Freeland pers. comm.).

The front is associated with a large scale circulation cell that may result from the seamount-induced pertur-

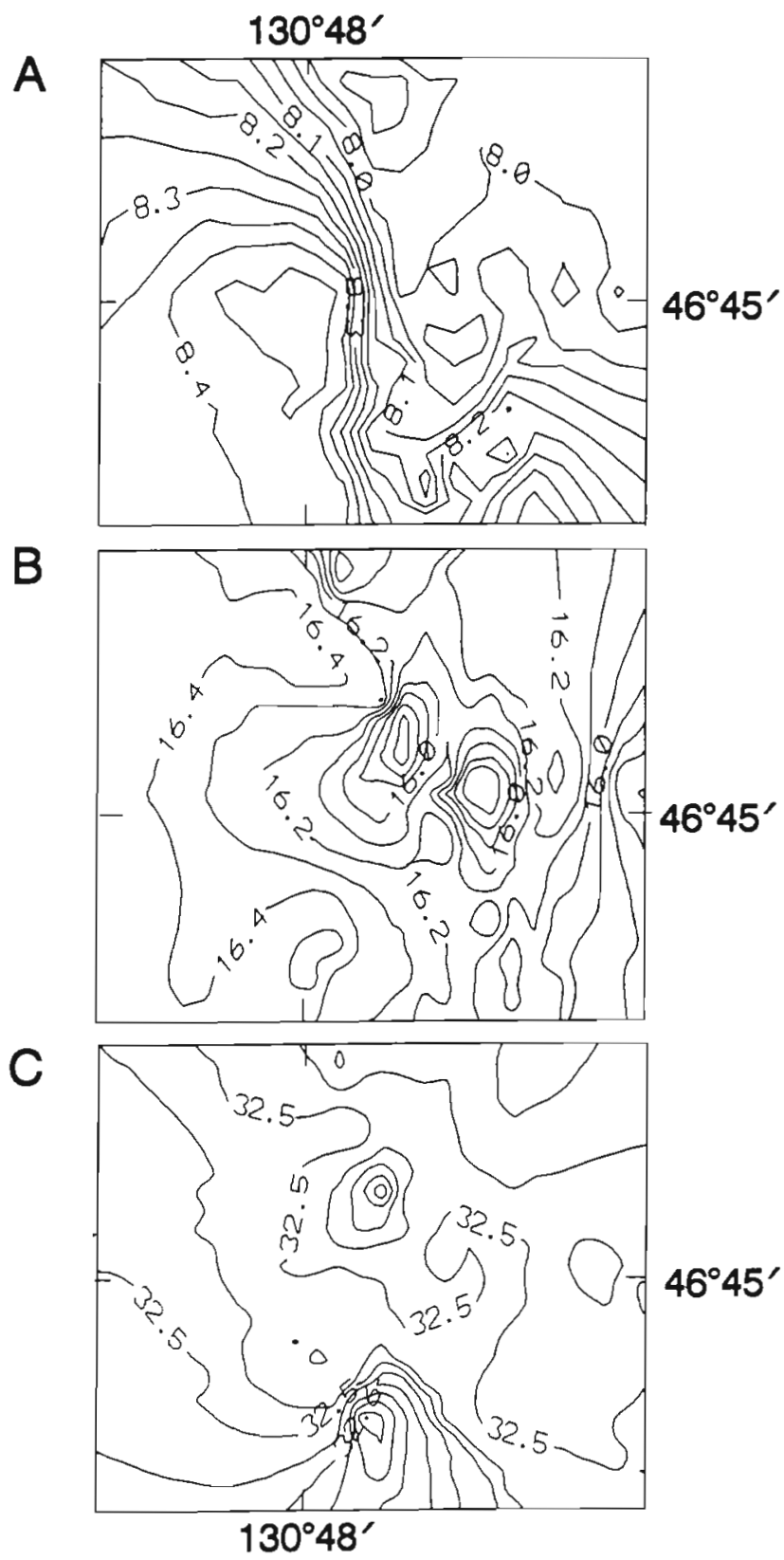

Fig. 2. Summary of physical features (temperature, salinity) around Cobb Seamount in August 1991. (A) Contour plot of temperature $\left({ }^{\circ} \mathrm{C}\right)$ on the isopycnal sigma-t $=25.4$ situated at the top of the permanent halocline between 80 and $90 \mathrm{~m}$; (B) surface $(10 \mathrm{~m})$ temperature; (C) surface $(10 \mathrm{~m}) \%$ salinity bation, but may also represent the confluence of different water masses.

\section{Species composition}

A total of 51 different ciliate taxa were identified and counted during this study. Two species, the tintinnid Amphorides quadralineata and an unidentified hypotrich, were found only at the QED station, far from Cobb Seamount. Ciliates were dominated by members of the subclass Choreotrichia (orders Choreotrichida and Oligotrichida; Small \& Lynn 1985). Particularly dominant were Laboea spp., Lohmanniella oviformis, Strobilidium (formerly Lohmanniella) spiralis, Strombidinopsis spp., and at times Tontonia of. appendiculariformis. Tintinnids of the genera Acanthostomella and Salpingella (except Salpingella acuminata which was very rare) were also commonly seen. Prostomatid ciliates consisted mainly of 2 species of Balanion while among other taxa, the larger Lacrymaria cf. rostrata (archistomatid ciliate) was commonly found. Ciliates ranged in size from $15 \mu \mathrm{m}$ in length to a very large individual, Salpingella acuminata $(350 \mu \mathrm{m})$, with the most abundant cells generally being 19 to $120 \mu \mathrm{m}$ length. The provisional list of ciliate taxa found around Cobb Seamount is presented in Table 2.

\section{Standing stock}

Total ciliate abundance at the survey stations ranged

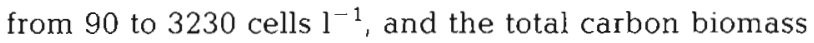
from 0.362 to $14.12 \mu \mathrm{g} \mathrm{Cl}^{-1}$. Ciliate biomass integrated to $80 \mathrm{~m}$ depth was substantially high (range 303.5 to $585.4 \mathrm{mg} \mathrm{C} \mathrm{m}^{-2}$, mean $415.7 \pm 78.0 \mathrm{mg} \mathrm{C} \mathrm{m}^{-2}$ ) and cell numbers were relatively low $\left(4.8\right.$ to $17.3 \times 10^{7}$ cells $\mathrm{m}^{-2}$, mean $7.4 \pm 2.7 \times 10^{7}$ cells $\mathrm{m}^{-2}$ ) (Table 3 ), as compared to other reports from the subarctic Pacific (e.g. Taniguchi 1984, Strom 1990). Depth-integrated biomass values had a smaller range of variability (1.9fold) than did depth-integrated abundance (3.6-fold). Integrated values of ciliate abundance and biomass were better correlated in a logarithmic regression model $\left(\mathrm{r}^{2}=63.1 \%, \mathrm{p}=0.00005, \mathrm{n}=19\right)$ than in a linear regression $\left(\mathrm{r}^{2}=26.3 \%, \mathrm{p}=0.02, \mathrm{n}=19\right)$.

Depth-integrated chl a values ranged from 1.2 to 31.6 $\mathrm{mg} \mathrm{m}^{-2}$ (mean $15.0 \pm 6.1 \mathrm{mg} \mathrm{m}^{-2}$ ) while integrated primary productivity varied from 83.9 to $1170.9 \mathrm{mg} \mathrm{C}$ $\mathrm{m}^{-2} \mathrm{~d}^{-1}$ (mean $467.4 \pm 311.9 \mathrm{mg} \mathrm{C} \mathrm{m}^{-2} \mathrm{~d}^{-1}$ ) (Table 3). No significant linear correlations were found between ciliate biomass and either of these variables. However, there is a suggestion that some of the peaks in ciliate biomass followed chlorophyll concentrations. In general, high values of ciliate density and chlorophyll 
Table 2. Groups of planktonic ciliate taxa counted in the samples, with greatest average linear dimensions and biovolumes of 30 to 50 preserved individuals

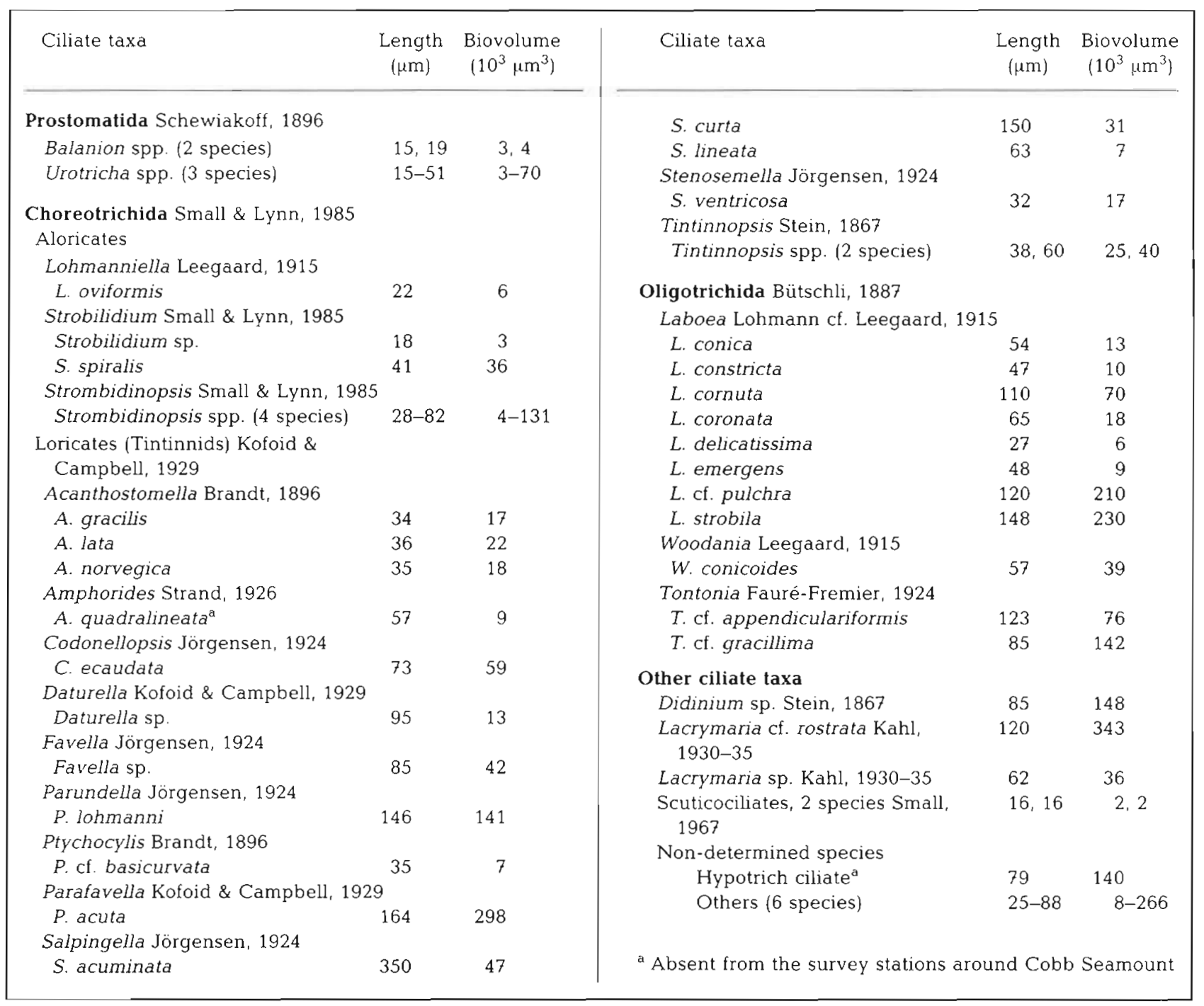

concentration appeared on the western flank of the seamount, along the salinity and temperature front (Fig. 2A). Nevertheless, the higher (>430 $\mathrm{mg} \mathrm{C} \mathrm{m}^{-2}$ ) values of ciliate biomass were more scattered and distributed immediately around the summit (Sites S1.2, S4.2, and S5.2) and to the southeastern (S4.4, S4.6) and western (S6.4, S6.6) flanks. The peak at Site S1.2 corresponded to the highest chlorophyll value. Spatial distribution of primary production was different from that of ciliates and chlorophyll, the most evident peaks were north of the seamount summit (Sites S1.6 and S2.2). Average cellular carbon was calculated by dividing depth-integrated cell biomass by cell numbers. These values ranged from $3 \mathrm{ng} \mathrm{C}$ cell ${ }^{-1}$ (S6.6) to $9 \mathrm{ng} \mathrm{C}$ cell $^{-1}$ (S1.2), the mean being $6 \pm 1.5 \mathrm{ng} \mathrm{C} \mathrm{Cell}^{-1}$ (Table 3).

Aloricate choreotrich and oligotrich species dominated the depth-integrated ciliate abundance and bio- mass (Table 4). Their relative contribution to these 2 variables varied from 37 to $64 \%$ (mean $52 \%$ ) and from 17 to $80 \%$ (mean $52 \%$ ) respectively. Common species were Lohmanniella oviformis, Strobilidium spiralis, Strombidinopsis spp., individuals of the genera Laboea, and at times Tontonia appendiculariformis. Tintinnid species were also relatively abundant (mean $14 \%$ ), due to their abundance on the western flank of the seamount ( $>30 \%$ of the integrated abundance), with the bulk of their biomass situated at Site S6.6, where they represented $64 \%$ of the total ciliate biomass (Table 4). Major species that constituted this apparent tintinnid intrusion were: Acanthostomella gracilis, Salpingella curta and Tintinnopsis sp. Apart from oligotrichs and choreotrichs, the prostomatid (almost all Balanion spp.) and 'other ciliates' categories represented, on average, 12 and $22 \%$ of the integrated total biomass respectively. 
The latter higher value is due to an invasion ( $56 \%$ of the integrated biomass) of Lacrymaria rostrata in the samples from Site S6.4 (Table 4).

Some of the taxa cited above, primarily the genus Laboea (McManus \& Fuhrman 1986, Stoecker et al. 1988) and Tontonia appendiculariformis (Laval-Peuto \& Febvre 1986, Laval-Peuto et al. 1986) are always mixotrophic because they sequester photosynthetically functional chloroplasts from a variety of chromophytic and chlorophytic algae (Jonsson 1987, Stoecker et al. 1987). Their relative contribution to the depth-integrated ciliate biomass (mean ca $40 \%$ ) was high around Cobb Seamount, as compared to the control Stns OFFSMT and QED (Table 4). The highest contribution $(77 \%)$ was noted through the shallow $(24 \mathrm{~m})$ summit water column. No significant linear correlations were found between mixotrophic ciliate biomass and either depth-integrated chl $a$ or primary productivity.

\section{Spatial structure}

Moran's $I$ and Geary's c were used to characterize the 2-dimensional spatial structure of depth-integrated ciliate abundance and biomass, chlorophyll concen- tration and primary production. For cilitate counts, significant positive and negative values of $I$, compared to the expected value $[\mathrm{E}(I)=-0.0588$ ], were found for 12 and $18 \mathrm{~km}$ distance classes respectively. Similar results were also obtained for Geary's $c$, the significant values being negative and positive for the 2 latter classes of distance, respectively $[E(c)=1]$ (Fig. 3). These results indicate that patchiness occurred within the ciliated protozoan community over the Cobb Seamount. The radius of the patches was likely near $13 \mathrm{~km}$ (between 12 and $18 \mathrm{~km}$ ), where the first zero of the Moran's correlogram is observed (Sokal 1979, Legendre \& Legendre 1984). Moreover, the second zero is observed at a distance class (ca $40 \mathrm{~km}$ ) about 3-fold higher than the first one. According to Platt et al. (1970) this indicates that the patches must be quasi-circular, and that the distances between patches approximately equal the diameter of patches. It appears that the abundance correlograms were strongly influenced by a single station at the western end of Spoke 6 (Site S6.6, Tables 3 \& 4). Exclusion of this station from the analysis suppressed all significant values on both Moran's and Geary's correlograms. The tintinnid invasion at Site S6.6 was thus responsible for observed abundance heterogeneity around the Cobb seamount.

Table 3. Integrated (from surface to $80 \mathrm{~m}$ ) ciliate abundance, biomass and average cell carbon (biomass abundance ${ }^{-1}$ ), chlorophyll a concentration, and primary productivity in the survey stations around Cobb Seamount during the first week of August 1991 , including the summit and Stns OFFSMT and QED (controls; cf. 'Methods') for ciliates. -: no data available

\begin{tabular}{|c|c|c|c|c|c|}
\hline Sites & $\begin{array}{l}\text { Ciliate number } \\
\left(10^{7} \text { cells } \mathrm{m}^{-2}\right)\end{array}$ & $\begin{array}{l}\text { Ciliate biomass } \\
\left(\mathrm{mg} \mathrm{C} \mathrm{m}^{-2}\right)\end{array}$ & $\begin{array}{l}\text { Average ciliate cell carbon } \\
\left(\mathrm{ng} C \text { cell }^{-1}\right)\end{array}$ & $\begin{array}{l}\text { Chlorophyll a } \\
\left(\mathrm{mg} \mathrm{m}^{-2}\right)\end{array}$ & $\begin{array}{l}\text { Primary productivity } \\
\qquad\left(\mathrm{mg} \mathrm{C} \mathrm{m}^{-2} \mathrm{~d}^{-1}\right)\end{array}$ \\
\hline $\mathrm{S} 1.2$ & 5.36 & 476.16 & 8.88 & 31.56 & 426.1 \\
\hline $\mathrm{S} 1.4$ & 6.02 & 346.22 & 5.75 & 14.64 & 628.5 \\
\hline S1.6 & 7.47 & 351.67 & 4.71 & 21.86 & 1170.9 \\
\hline $\mathrm{S} 2.2$ & 8.24 & 392.06 & 4.76 & 16.55 & 1153.3 \\
\hline $\mathrm{S} 2.4$ & 6.87 & 341.62 & 4.97 & 17.97 & 559.5 \\
\hline $\mathrm{S} 2.6$ & 8.73 & 398.86 & 4.57 & 12.59 & 257.6 \\
\hline S3.2 & 6.03 & 347.21 & 5.76 & 14.53 & 108.7 \\
\hline S3.4 & 4.76 & 378.85 & 7.96 & 17.10 & 363.1 \\
\hline S3.6 & 5.80 & 343.38 & 5.92 & 9.11 & 245.1 \\
\hline $\mathrm{S} 4.2$ & 6.18 & 492.20 & 7.96 & 8.16 & 404.1 \\
\hline S 4.4 & 6.77 & 437.28 & 6.46 & 14.32 & - \\
\hline S4.6 & 7.06 & 546.05 & 7.73 & 1.17 & 247.5 \\
\hline 55.2 & 6.98 & 474.79 & 6.80 & 12.91 & 83.9 \\
\hline S5.4 & 6.55 & 391.69 & 5.98 & 13.03 & - \\
\hline \$5.6 & 9.45 & 368.60 & 3.90 & 16.07 & 404.4 \\
\hline S6.2 & 6.17 & 303.53 & 4.92 & 14.94 & 374.5 \\
\hline S6.4 & 7.92 & 585.42 & 7.39 & 12.28 & - \\
\hline S6.6 & 17.32 & 506.41 & 2.92 & 21.22 & 583.6 \\
\hline Summit ${ }^{\mathrm{a}}$ & 1.46 & 90.10 & 6.17 & - & - \\
\hline OFFSMT & 1.62 & 111.24 & 6.87 & - & - \\
\hline QED & 9.75 & 249.85 & 2.56 & - & - \\
\hline
\end{tabular}


For integrated biomass, only the Geary's $c$ was positively significant for the first class of distance $(6 \mathrm{~km})$. Such a result generally indicates that the diameter of patches is inferior or equal to the distances $(6 \mathrm{~km})$ between classes (Legendre \& Legendre 1984). Furthermore, this shape of correlogram, with a significant positive value in a low distance class could indicate a spatial gradient, but to confirm this, significant negative autocorrelations must necessarily occur in the higher distance classes (Sokal 1979, Legendre \& Legendre 1984). Such was not the case here. A similar pattern was found for chl a concentration (Fig. 3), due to the peaks at S1.2, S1.6 and S6.6 (Table 3). For primary productivity, neither autocorrelation coefficient was not significant, and the correlograms for this variable are not plotted here.

\section{Vertical profiles}

In general, ciliate density peaked at 25 and $50 \mathrm{~m}$ while biomass was highest in the upper water column at 10 and $30 \mathrm{~m}$, due to the dominance of oligotrichs near the surface, especially the large species of the genus Laboea. Values of both parameters decreased below 30 to $50 \mathrm{~m}$ (Fig. 4), although there was occasionally a subsurface minimum. This was more pronounced for abundance (e.g. all sites of Spoke 2, S3.4, S4.4, S5.2, S5.4, S6.4, S6.6) than with biomass (e.g. S6.6). Biomass peaks at times corresponded to peaks in chlorophyll (e.g. S2.6, S3.2, S3.6, Spoke 6) or primary production (Spoke 1, S3.6, S4.6; Figs. 4 \& 5); however, significant vertical structure was only noted with chlorophyll. [The Kendall coefficient of concordance $(w)$ revealed a fairly closed vertical distribution of chlorophyll and both ciliate abundance $(w=0.357, p<0.0001)$ and biomass ( $w=0.330, p<0.0001)$.] The highest ciliate abundance was observed at $30 \mathrm{~m}$ at Site S6.6 (Fig. 4), where tintinnids dominated (Table 4), contributing 1800 cells $1^{-1}$ to total ciliate numbers (ca 2300 cell $1^{-1}$ ) at this depth.

\section{DISCUSSION}

While the general dominance of aloricate choreotrich and oligotrich ciliates agrees with results from most marine systems (Smetacek 1981, Beers et al. 1982, Garrison \& Buck 1989, Stoecker et al. 1989, Dolan 1991), including coastal regions, the planktonic ciliate

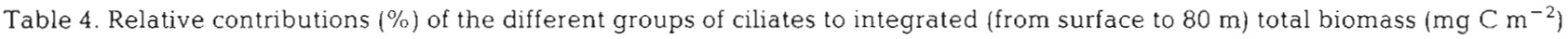
from survey stations around Cobb Seamount during the first week of August 1991, including the summit and Stns OFFSMT and QED (controls, cf. Methods')

\begin{tabular}{|c|c|c|c|c|c|}
\hline Sites & Prostomatida & $\begin{array}{c}\text { Choreotrichida (aloricates) } \\
\text { and Oligotrichida }\end{array}$ & Tintinnida & $\begin{array}{l}\text { Other ciliate } \\
\text { taxa }\end{array}$ & $\begin{array}{l}\text { Mixotrophic } \\
\text { taxa }\end{array}$ \\
\hline $\mathrm{S} 1.2$ & 7.6 & 63.1 & 3.3 & 26.0 & 46.6 \\
\hline S1.4 & 8.1 & 79.6 & 5.4 & 6.9 & 47.9 \\
\hline $\mathrm{S} 1.6$ & 19.1 & 66.7 & 6.9 & 7.3 & 41.2 \\
\hline $\mathrm{S} 2.2$ & 23.9 & 41.4 & 16.5 & 18.2 & 32.6 \\
\hline$\$ 2.4$ & 12.0 & 50.5 & 17.3 & 20.2 & 37.1 \\
\hline $\mathrm{S} 2.6$ & 8.3 & 52.3 & 13 & 26.4 & 37.5 \\
\hline S3.2 & 23.4 & 67.2 & 4.8 & 4.6 & 45.3 \\
\hline S3.4 & 12.7 & 71.3 & 4.6 & 11.4 & 50.2 \\
\hline S3.6 & 8.5 & 75.2 & 7.2 & 9.1 & 50.2 \\
\hline $\mathrm{S} 4.2$ & 10.5 & 70.5 & 7.3 & 11.7 & 58.7 \\
\hline 54.4 & 20.5 & 42.8 & 8.3 & 28.4 & 40.9 \\
\hline $\mathrm{S} 4.6$ & 12.4 & 42.5 & 6.1 & 39.0 & 41.2 \\
\hline S5.2 & 5.4 & 62.6 & 7.3 & 24.7 & 45.3 \\
\hline 55.4 & 14.4 & 60.2 & 5.7 & 19.7 & 47.9 \\
\hline S5.6 & 1.0 & 41.3 & 36.4 & 21.3 & 38.8 \\
\hline S6.2 & 18.2 & 39.2 & 20.5 & 22.1 & 26.4 \\
\hline S6.4 & 10.9 & 16.9 & 16.3 & 55.9 & 16.5 \\
\hline S6.6 & 2.6 & 27.8 & 64.0 & 5.6 & 18.3 \\
\hline Summit ${ }^{a}$ & 11.1 & 84.1 & 4.5 & 0.3 & 76.9 \\
\hline OFFSMT & 19 & 55.2 & 9.1 & 16.7 & 20.0 \\
\hline QED & 25.3 & 49.9 & 4.2 & 20.6 & 15.3 \\
\hline
\end{tabular}



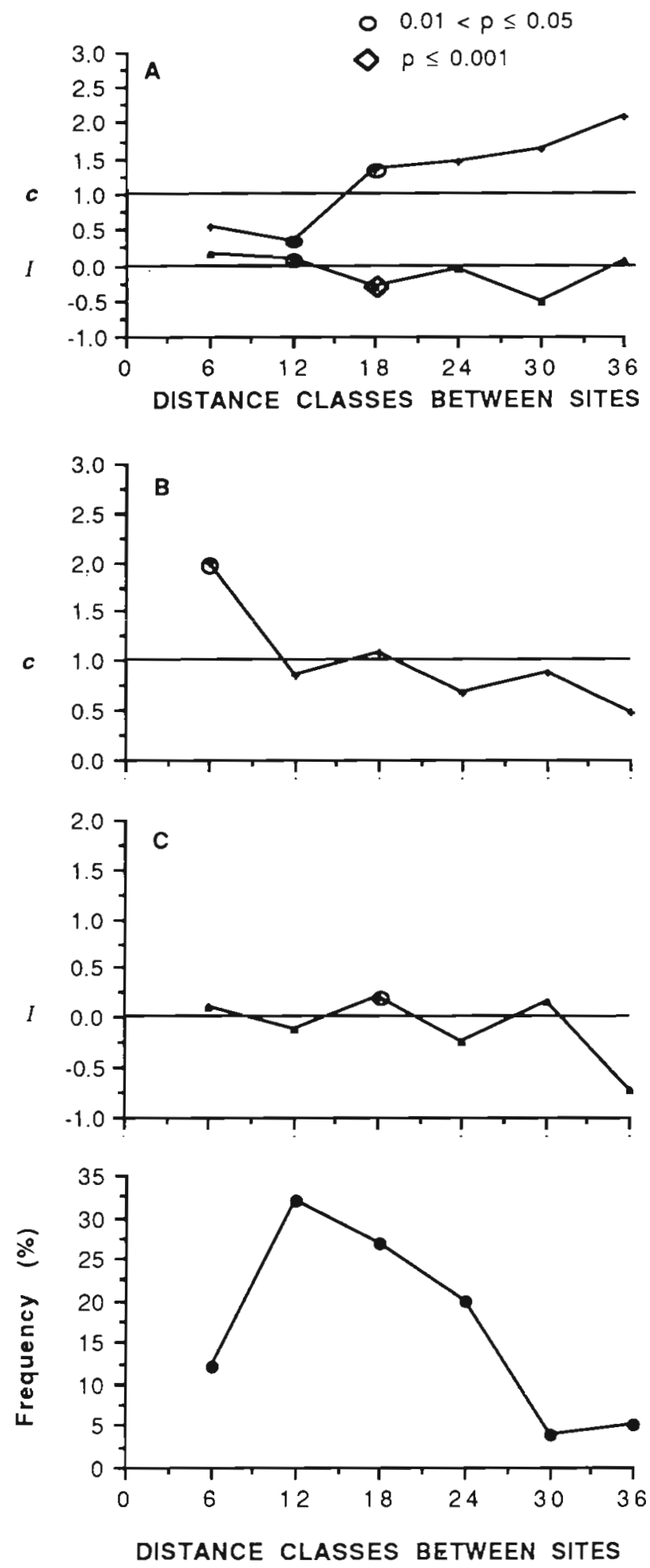

Fig. 3. Geary's $C$ and Moran's $I$ as a function of distances between sites for (A) integrated (from surface $1080 \mathrm{~m}$ ) ciliate abundance, and (B) biomass and (C) chlorophyll a concentration. Mathematical expectancies of $c$ and $I$ under the hypothesis of a completely random spatial distribution are not zero, but $E(c)=1.0000$ and $E(I)=-0.0588$. Bottom graph indicates frequency of occurence of each distance class populations which live around Cobb Seamount are unusually diversified. We were able to identify 49 different taxa, ranging in size from 15 to $350 \mu \mathrm{m}$ length. Our species list (Table 2) must be considered to be provisional. We are presently completing a multi-year taxonomic report on common microzooplanktonic populations in the Cobb Seamount region (SimeNgando et al. unpubl.). The taxonomic characterization of natural ciliate populations frequently is very incomplete, in both marine and freshwater environments (Fenchel 1987, Finlay et al. 1988, Foissner 1988), partly due to the inadequate nature of routine methods (e.g. Sime-Ngando et al. 1990, Sime-Ngando \& Grolière 1991). During a summer study in the Chukchi and Bering seas and the northern North Pacific Ocean, Taniguchi (1984) found less than 36 different ciliate taxa, with sizes ranging from 16.6 to $279.5 \mu \mathrm{m}$ length. In the eastern subarctic Pacific, ciliate sizes varied from 5 to $120 \mu \mathrm{m}$ in length (Strom 1990), but no exhaustive list of species is available. Often, ciliates are grouped by size, with occasional emphasis of dominant higher taxonomic groups, to define their ecological importance. Nevertheless, within a planktonic community, ciliate populations may be highly diverse, occupying several different trophic compartments (Pratt \& Cairns 1985, Sime-Ngando \& Hartmann 1991, Sime-Ngando et al. unpubl.), regardless of size. Thus, in order to correctly assign trophic categories, routine quantitative ciliate counts should give well-defined species compositions.

Ciliate density around Cobb Seamount was relatively low, compared to summertime densities in most marine systems, including cold water masses. Total abundance ranged between 90 and 3230 cells $\mathrm{l}^{-1}$ (Fig. 4). For both coastal and open ocean regions, ciliate numbers range from 234 to 47000 cells $\mathrm{l}^{-1}$; the eastern subarctic Pacific values being from 500 to 28000 cells $1^{-1}$ (e.g. comparative table in Strom 1990). The highest value of 47000 cells $1^{-1}$ was recorded in the western subantarctic Pacific by Tumantseva (1982). Our results are similar to those of the western subarctic

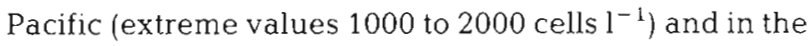
Weddell Sea ice edge (1.4 to 2340 cells $\left.^{-1}\right)$ reported by Taniguchi (1984) and Garrison \& Buck (1989) respectively.

In contrast to abundances, ciliate biomass over Cobb (extreme values 0.4 to $14 \mu \mathrm{g} \mathrm{C} \mathrm{l}{ }^{-1}$, integrated values 304 to $585 \mathrm{mg} \mathrm{C} \mathrm{m}^{-2}$ ) was substantially higher than in other oceanic regions, including Stns OFFSMT and QED (Fig. 4, Table 3). In subantarctic and Antarctic waters where the greatest ciliate densities have been reported (see above), the average integrated (0 to 150 $\mathrm{m}, 200 \mathrm{~m}$ ) biomass does not exceeded $150 \mathrm{mg} \mathrm{C} \mathrm{m}^{-2}$. In Saanich Inlet (Canada), where ciliate numbers ranged from 1700 to 11880 cells $1^{-1}$, the depth-integrated bio- 
mass to $25 \mathrm{~m}$ for all microzooplanktonic organisms was less than $18 \mathrm{mg} \mathrm{C} \mathrm{m}^{-2}$ (Takahashi \& Hoskins 1978), similar to values for some of the oceanic stations compared by Taniguchi (1984). The high $\mathrm{HgCl}_{2}$-fixed ciliate biomass observed here (mean $416 \pm 78 \mathrm{~m} \mathrm{C} \mathrm{m}^{-2}$ ) cannot be entirely due to biases created by cell shrinkage (Choi \& Stoecker 1989) in other studies or cell volume: cell carbon conversion factors (mostly determined from acid Lugol-or formalin-fixed individuals) that differ from that used here, since values remain relatively high even if we assume a cell measurement error of $50 \%$. Moreover, using the same conversion factor for cell volume: cell carbon $\left(1 \mu \mathrm{m}^{3}=0.19 \mathrm{pg} \mathrm{C}\right.$ for $2 \%$ Lugol-fixed cells; Putt \& Stoecker 1989) employed in this study, Strom (1990) reported low depth-integrated (to $80 \mathrm{~m}$ ) ciliate (preserved in Lugol) biomass (from 95 to $358 \mathrm{mg} \mathrm{C} \mathrm{m}{ }^{-2}$, mean $159 \pm 37.1$ mg C m ${ }^{-2}, n=10$ ) compared to our results (Table 3 ), for Stns $P$ and $R$ situated northwest of Cobb Seamount.

Cell volume estimates, from which ciliate biomass is frequently calculated, may differ depending on the fixative used, although differences among common fixatives generally do not exceed $25 \%$. Using an electronic particle counter, Ohman \& Snyder (1991) showed that Strombidium sp. fixed in 1 and $2 \%$ acid Lugol's solution, $1 \%$ glutaraldehyde and $1 \%$ buffered formaldehyde shrunk $21,26,3$ and $3 \%$ more respectively than specimens in $2 \%$ neutral Lugol's solution or $1 \%$ unbuffered formaldehyde. For several oligotrichous ciliates (Laboea strobila, Strombidium sp., and $S$. spiralis), Putt \& Stoecker (1989) microscopically determined that volume of cells preserved in $2 \%$ acid Lugol's solution averaged $76 \%$ of $2 \%$ buffered formalin-preserved cells. To better observe differences between our $\mathrm{HgCl}_{2}$ preservation method and acid Lugol's (2\%) fixation, both fixatives were used to preserve natural assemblage of ciliates collected in July 1992 at $10 \mathrm{~m}$ (chlorophyll maximum) depth of the St. Lawrence Maritime Estuary $\left(48^{\circ} 57^{\prime} \mathrm{N}, 68^{\circ} 26^{\prime} \mathrm{W}\right)$. A total of 20 to 50 individuals of each of the 9 dominant taxa were microscopically sized (Table 5). Cell volumes of Lugol's-preserved cells averaged $80 \%$ (median
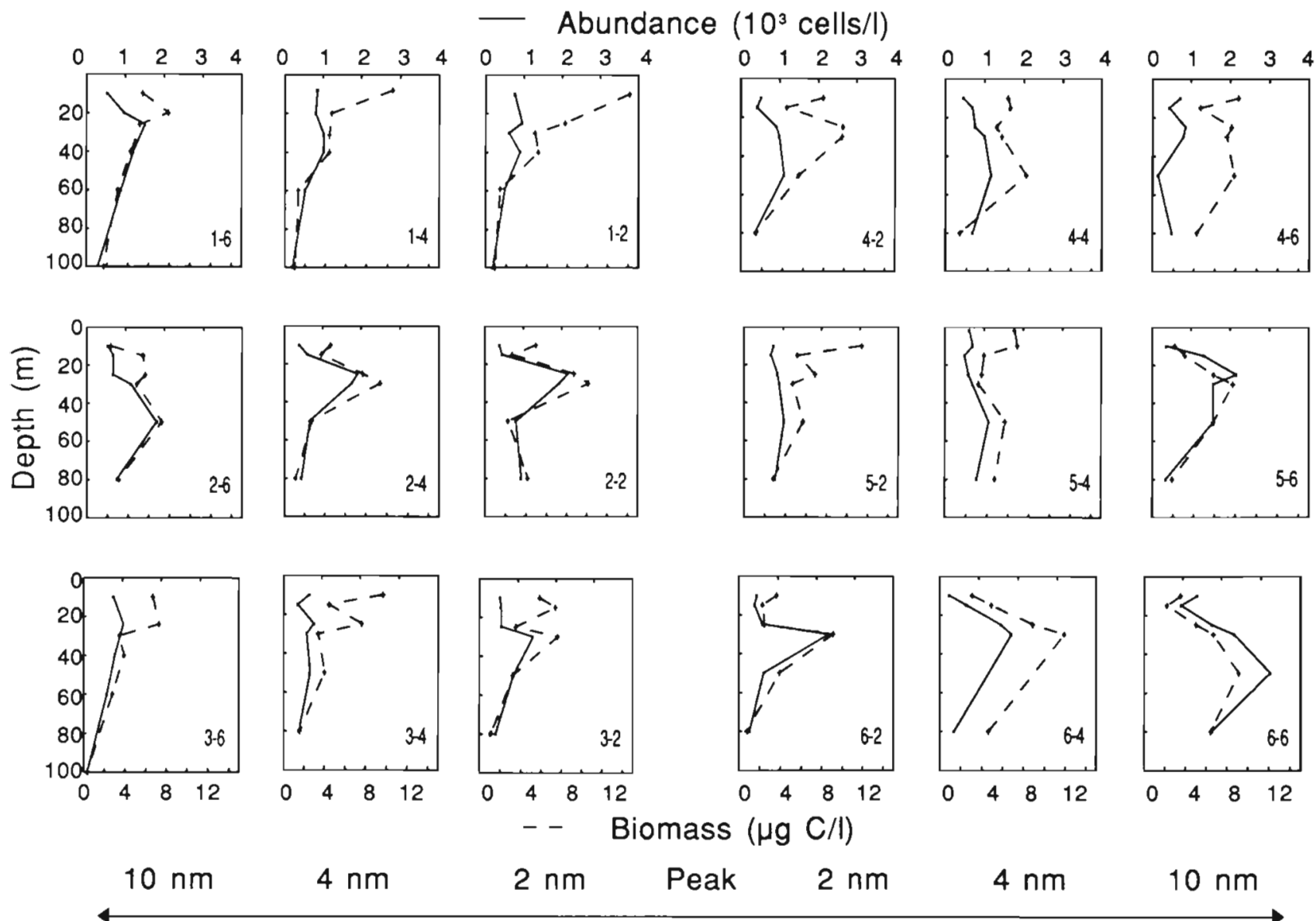

$4 \mathrm{~nm}$

$2 \mathrm{~nm}$

Peak

$2 \mathrm{~nm}$

$4 \mathrm{~nm}$

$10 \mathrm{~nm}$

Fig. 4. Ciliate number and biomass vs depth on the 3 transects of survey stations over the Cobb Seamount during the first week of August 1991. Numbers in plots $(x-y)$ : Spoke $x$, Site $y$ (see Fig. 1, Table 1) 
value $78 \%$; Table 5) of $\mathrm{HgCl}_{2}$-preserved cells. According to this result, the mean ciliate biomass over Cobb of $333 \mathrm{mg} \mathrm{C} \mathrm{m}^{-2}$ remains high, compared to values from other studies.

One possible explanation for the generally high ciliate biomass around Cobb Seamount is an enriched food supply. The zone of elevated phytoplankton biomass around the seamount summit observed by Dower et al. (1992) in 1990 (up to $122.4 \mathrm{mg} \mathrm{chl} \mathrm{a} \mathrm{m}^{-2}$ ) essentially encompasses the area studied in 1991. However, chl a values in summer 1991 were considerably lower than those observed in 1990. If we compare our data to

Table 5. Comparison of cell volumes of ciliates determined microscopically for material preserved with mercuric chloride ( $\mathrm{HgCl}$ $2.5 \%, \mathrm{v} / \mathrm{v})$ and acid Lugol's iodine $(2 \% \mathrm{v} / \mathrm{v})$. Volumes are mean cell volume after 1 wk preservation, $\mathrm{n}=20$ to 50 cells. Samples originated from $10 \mathrm{~m}$ depth of the St. Lawrence Maritime Estuary (48 $\left.57^{\prime} \mathrm{N}, 68^{\circ} 26^{\prime} \mathrm{W}\right)$

\begin{tabular}{|c|c|c|c|}
\hline \multirow[t]{2}{*}{ Ciliate taxa } & \multicolumn{2}{|c|}{$\begin{array}{l}\text { Mean cell volume (SE) } \\
\qquad\left(\mu \mathrm{m}^{3} \times 10^{3}\right)\end{array}$} & \multirow{2}{*}{$\begin{array}{c}\text { Ratio } \\
\text { Lugol : } \mathrm{HgCl}_{2}(\%)\end{array}$} \\
\hline & $\mathrm{HgCl}_{2}$ & Lugol & \\
\hline Strombidinopsis sp. & $51.72(1.53)$ & $31.99(0.90)$ & 61.8 \\
\hline Laboea sp. & $14.04(0.74)$ & $8.98(1.13)$ & 64.0 \\
\hline Lohmanniella oviformis & $5.41(0.43)$ & $3.92(0.48)$ & 72.5 \\
\hline Stenosemella sp. & $51.25(3.03)$ & $39.43(2.03)$ & 76.9 \\
\hline Tontonia sp. & $297.39(6.90)$ & $231.98 \quad(5.05)$ & 78.0 \\
\hline Strombidium sp. & $83.91(4.05)$ & $65.90(4.01)$ & 78.5 \\
\hline Didinium sp. & $43.99(2.48)$ & $35.83(3.68)$ & 81.4 \\
\hline Laboea emergens & $7.36(0.34)$ & $6.70(0.77)$ & 91.0 \\
\hline Tintinnopsis sp. & $55.87 \quad(4.67)$ & $61.36(3.22)$ & 109.8 \\
\hline
\end{tabular}

- Chlorophyll $\underline{a}\left(\mathrm{mg} / \mathrm{m}^{3}\right)$
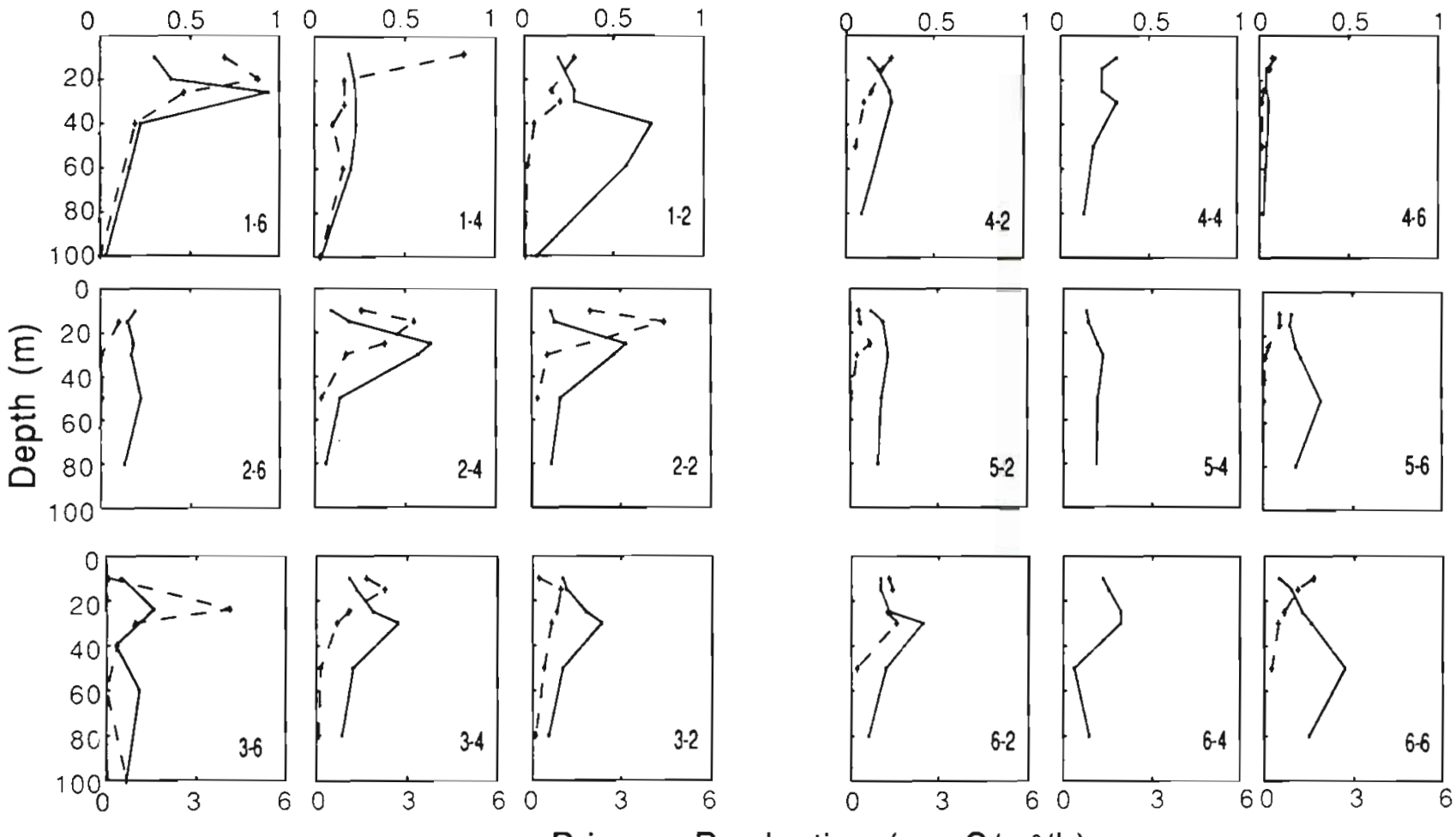

- Primary Production $\left(\mathrm{mg} \mathrm{C} / \mathrm{m}^{3} / \mathrm{h}\right)$

$\begin{array}{rlllll}10 \mathrm{~nm} & 4 \mathrm{~nm} & 2 \mathrm{~nm} & \text { Peak } \quad 2 \mathrm{~nm} & 4 \mathrm{~nm} & 10 \mathrm{~nm}\end{array}$

Fig. 5. Chlorophyll a concentration and primary productivity vs depth on the 3 transects of the survey stations over the Cobb Seamount during the first week of August 1991. Site numbers as in Fig. 4 
those of Strom (1990), we cannot explain the higher ciliate biomass at Cobb Seamount in terms of a similar increase in phytoplankton stock or productivity. While average depth-integrated ciliate biomass at Cobb Seamount is ca twice that observed by Strom (1990) for Stns $\mathrm{P}$ and $\mathrm{R}$, chlorophyll and primary productivity values (Table 3) for the 2 studies are similar (Strom reports 12.1 to $39.6 \mathrm{mg} \mathrm{m}^{-2}$ and 140 to $1340 \mathrm{mg} \mathrm{C} \mathrm{m}^{-2}$ $\mathrm{d}^{-1}$ for chl a and primary productivity respectively, integrated to $80 \mathrm{~m}$ ). In a return visit to Cobb in summer 1992, chl a values were in the same range as in 1991 ( $\mathrm{T}$. Sime-Ngando pers. observ.).

While no simply mechanism involving food supply appears to account for the high ciliate biomass around Cobb Seamount, there are several possible explanations for the increase in ciliate size, compared to other sites. Firstly, before referring to the specific habitat conditions of waters overlying the seamount, biogeographic influences must be considered. Although few descriptions of ciliate communities in the oceanic Pacific are complete enough to permit characterization of major regions, some comparison is possible. For example, Cobb Seamount is at the southeastern limit of the subarctic Pacific and Stns P and R (e.g. Strom $1990)$ are in the central portion of this oceanic region. The average cell carbon calculated for the Cobb Seamount sites is nearly 10 times that estimated for ciliates at Stns P and R by Strom (1990). Stn QED, situated much closer to the central portion of the subarctic Pacific than to Cobb Seamount, was also characterized by a much lower average cell carbon value than the Cobb stations. Furthermore, the only taxonomic differences in terms of presence or absence of species noted in our study, are between Stns QED Cobb. Two species present at Stn QED, including a dominant species (Amphorides quadralineata), were absent at Stn Cobb. Stn OFFSMT, which is much closer to the Cobb area than Stn QED (Table 1), showed the same species composition and average cell carbon as the Cobb stations, although it had much lower numbers and thus a lower total biomass. Although information is limited, it appears that the composition of the Cobb Seamount ciliate community may be characteristic of its general region.

Secondly, it is also useful to seek explanation for the large size of Cobb Seamount ciliates in the ecological conditions particular to the seamount itself. As we have mentioned above, ciliates operate in several trophic compartments in marine and freshwater ecosystems. The large contribution of mixotrophic forms (mean $40 \%$ ) to total ciliate biomass over the seamount may be related to local conditions favoring their growth. Since some of the mixtrophic species, such as Laboea cf. pulchra, L. strobila and Tontonia spp., are among the larger cilates found in our sam- ples, local enhancement of mixotroph abundance around Cobb Seamount could have a significant effect on total ciliate biomass. This is supported, in part, by the observations at Stns OFFSMT and QED, where total ciliate biomass is lower and where mixotrophic taxa contribute only 20 and $15.3 \%$ respectively to the total (Table 4). However, as mentioned above, average cell carbon at Stn OFFSMT was similar to that of seamount stations. Thus increased mixotrophy would not augment total biomass through a simple effect on average cell size. Rather, within this region where average cell size is already larger than elsewhere, mixotrophic species could locally increase their contribution to the ciliate biomass already supported by heterotrophic activity, by becoming more abundant. Unfortunately, Strom (1990) and other workers do not give enough taxonomic detail to estimate the contribution of mixotrophs to total ciliate biomass elsewhere in the Pacific.

Thirdly, predation rates of metazooplankton may be lower, resulting in larger sized ciliates. It is known that gut clearance rates of ciliate predators, primarily copepods which were the common larger zooplankton in our samples, are usually higher for large than for small ciliates (Stoecker \& Egloff 1987). Larger metazooplankton were not abundant in our samples (see below) although, they can be more abundant in the upper water column at night (Genin et al. 1988).

Finally, predominance of larger microalgae, which are more appropriate prey for bigger ciliates than for small ones (Rassoulzadegan et al. 1988), may be an alternative explanation for the observed increase in ciliate size. We are presently completing analyses of phytoplankton size-class distribution and energy flow through the Cobb Seamount phytoplankton and microheterotrophic communities. This should permit us to critically examine the underlying causes of the unusually high ciliate biomass at Cobb Seamount (Vézina et al. unpubl.).

Seamount-related physical perturbations have been proposed to intensify patchiness among net-zooplankton and rockfishes (Genin et al. 1988). We are unable to explain the patchiness of ciliates around Cobb Seamount without invoking the physical perturbations created by this topographic feature (Dower et al. 1992). For example, processes such as front and eddy formation locally increase environmental heterogeneity around Cobb Seamount, a situation that could favour opportunistic species such as tintinnids. Apparent horizontal patchiness in ciliate abundances around Cobb $(12$ to $18 \mathrm{~km})$ was strongly influenced by the invasion of tintinnids at Site S6.6 (Tables 3 \& 4, Fig. 4), situated west of the salinity and temperature front (Fig. 2A). Tintinnid abundances $\left(1800\right.$ cells $1^{-1}$ and 1600 cells $l^{-1}$ at 30 and $50 \mathrm{~m}$ respectively) were near those of the 
coastal waters, where densities of 1000 to $5000{\text { cells } l^{-1}}^{-1}$ are usually found. Abundance values for oceanic tintinnid populations are usually about 1 order magnitude lower than this (e.g. Taniguchi 1984).

Blooms of tintinnids can occur during warm seasons (spring-summer), as has been reported for the Narraganset Bay (Rhode Island, USA) by Hargraves (1981) and in the Damariscotta River estuary (Maine, USA) by Sanders (1987). Both these authors indicate that this does not necessarily imply a direct effect of temperature, since day length, food supply and predator abundance also increase during warm season. Nevertheless, some taxa such as Ptychocylis and Parafavella acuta do have geographical ranges restricted to cold water masses (Marshall 1969). Hargraves (1981) suggests that the most direct effect of temperature on tintinnids is most likely to be exerted on annual fauna changes and biogeography. As opposed to these seasonal and geographic controls on tintinnid abundance, we propose that the physical patchiness around Cobb Seamount can generate microhabitats that favor the growth of opportunistic populations.

The smaller patch dimensions for ciliate biomass ( $\leq 6 \mathrm{~km}$ diameter) result from biomass peaks being more evenly scattered and closer together than density peaks (Table 3). Patchiness here was not simply a result of intrinsic heterogeneity of size distribution, but due rather to the dominance of particular populations. Thus, in addition to the western patches of tintinnids and Lacrymaria of. rostrata (S6.4, see 'Results'), other biomass peaks were created by different species. For example, the higher depth-integrated biomass at all stations of Spoke 4 was due to Tontonia cf. appendiculariformis, while the peaks at Sites S1.2 and S5.2 were closed to the strong appearance of Laboea strobila and Laboea emergens, respectively.

The Cobb Seamount ciliates appear to counterbalance their low numbers by increasing in size, probably due to the exclusion of small common planktonic species (Strobilidium spp., scuticociliates and hymenostome-like cells) by larger cells, especially plastidic oligotrichs of the genera Laboea and Tontonia, in the subsurface waters. These individuals, particularly L. strobila (McManus \& Fuhrman 1986, Stoecker et al. 1988) and T. appendiculariformis (LavalPeuto \& Febvre 1986, Laval-Peuto et al. 1986) always contain functional chloroplasts and are considered as mixotrophic (Jonsson 1987, Stoecker et al. 1987). Their contribution of $40 \%$ to total ciliate biomass may be overestimated since all the species of the genus Laboea were considered together. Occasionally, it was not possible to accurately separate species because some specimens were badly distorted during our routine counts. The high contribution of mixotrophic taxa to the shallow (24 m) depth-integrated ciliate biomass on the
Cobb summit (Table 4) is most likely suggestive of their light-dependent functioning. They may be capable of interfering with estimation of phytoplankton biomass based on chlorophyll concentration and probably have the effect of reducing the number of trophic transfers between primary producers and both larger herbivores (McManus \& Fuhrman 1986, Stoecker et al. 1987) and heterotrophic bacteria. During our cruise, trophic transfer from primary producers to bacteria was at times very inefficient ( $M$. Bourgeois pers. comm.). We intend to investigate the autotrophic capabilities of $L$. strobila and $T$. appendiculariformis in the future.

Significant correlations were not found between depth-integrated ciliate biomass and either primary production or chlorophyll. This was probably due to the predominance of rhizosolenid diatoms in most samples, which probably constituted an important part of the chl $a$ and primary productivity around Cobb during our study. These organisms occur stochastically (bloom) in open ocean regions and may participate significantly in the mass sinking (Sancetta et al. 1991). They cannot be ingested by ciliates because of their large ( $>300 \mu \mathrm{m})$ size (Rassoulzadegan et al. 1988). Thus, the chlorophyll concentration and primary production were poor indicators of ciliate food resources during our cruise. Nevertheless, ciliate peaks (including average cellular carbon) at times followed the peaks of both algal parameters (Table 3, Figs. 4 \& 5), suggesting some direct influence of autotrophic production on ciliates; the vertical structure of ciliate biomass being significantly similar to that of chlorophyll. However, this may reflect the long-term evolution and vertical stratification of both variables, i.e. higher subsurface ciliate biomass coincided with the chlorophyll maximum layer. Primary production usually peaked at a few meters above the ciliate and chlorophyll maxima and values were usually close to zero under $50 \mathrm{~m}$ depth (Figs. 4 \& 5).

Direct observations showed that macrozooplankton (nauplius larvae, copepods, rotatoria) were poorly represented in our samples $\left(<50\right.$ ind. $1^{-1}$ ). Ciliate competitors such as foraminifera, radiolarians, rotifers and pteropod larvae also formed minor constituents of microzooplankton assemblage. From these observations, we conclude that (in addition to the heterotrophic dinoflagellates which are important members of microzooplankton in the North Pacific; Lessard 1991, Strom 1991), ciliated protozoans are important components of the microzooplankton assemblage over the Cobb, and are probably major grazers of microalgae. This is agrees with observations in oceanic waters north of Cobb (e.g. Frost 1987), recently confirmed by Strom (1990).

In conclusion, this study provides first evidence for enhancement of ciliate biomass over seamounts, complimenting other reports of increased primary producer 
biomass and enrichment at higher trophic levels in this milieu. We propose that the observed spatial patchiness is caused by physical forcing which increases habitat heterogeneity and scatters biological resources. This phenomenon may generate suitable microhabitats for the growth of opportunistic or physiologically adapted populations. Direct observations show ciliates to be a major component of the microzooplankton assemblage. Their grazing rates, growth rates and influence on phytoplanktonic production and nutrient regeneration rates remain unanswered, as do questions regarding mixotrophy, competition with other classes of herbivores such as heterotrophic dinoflagellates, and the role of predation. Nevertheless, we believe that this study constitutes a rather promising basis for quantitative and functional study of microzooplankton populations over seamounts.

Acknowledgements. This study was funded by the FCAR Québec, NSERC Canada, DFO Canada and the Université du Québec à Rimouski. T.S.N, was supported by a visiting research fellowship from the Université du Québec à Rimouski. We thank V Tunnicliffe, J. Dower and the Master and crew of the CSS 'Parizeau' for their collaboration during the time spent at sea. K. Wilson, D. Yelland and R. Bigham provided technical assistance at sea. L. Comeau and $M$. Bourgeois kindly allowed us to use their primary productivity and chlorophyll data. We thank Dr M. Gosselin and 2 anonymous reviewers for helpful suggestions to improve the manuscript.

\section{LITERATURE CITED}

Beers, J. R., Reid, F. M. H., Stewart, G. L. (1982). Seasonal abundance of the microplankton populations in the North Pacific central gyre. Deep Sea Res. 29: 227-245

Bernstein, R. L., White, W B. (1977). Zonal variability in the distribution of eddy energy in the mid-latitude North Pacific Ocean. J. phys. Oceanogr. 7: 123-126

Bodian, D. (1937). The staining of paraffin sections of nervous tissue with activated protargol. The role of fixatives. Anat. Rec. 69: 153-162

Boehlert, G. W., Genin, A. (1987). A review of the effects of seamounts on biological processes. In: Keating, B. H., Fryer, P., Batiza, R., Boehlert, G. W. (eds.) Seamounts, islands and atolls. Geophysical Monograph 43. American Geophysical Union, Washington, DC, p. 319-334

Cheney, R. E., Richardson, P. L., Nagasaka, K. (1980). Tracking a Kuroshio cold ring with a free-drifting surface buoy. Deep Sea Res. 27: 641-654

Choi, J. W., Stoecker, D. K. (1989). Effects of fixation on cell volume of marine planktonic protozoa. Appl. environ. Microbiol. 55: 1761-1765

Cliff, A. D., Ord, J. K. (1973). Spatial autocorrelation. Pion Limited, London

Cliff, A. D., Ord, J. K. (1981). Spatial processes: models and applications. Pion Limited, London

Dolan, J. R. (1991). Guilds of ciliate microzooplankton in the Chesapeake Bay. Est. coast. Shelf Sci. 33: 137-152

Dower, J., Freeland, H., Juniper, K. (1992). A strong biological response to oceanic flow past Cobb seamount. Deep Sea Res. 39: 1139-1145
Dragesco, J., Dragesco-Kerneis, A. (1986). Ciliés libres de l'Afrique intertropical. Introduction à la connaissance et à l'étude des Ciliés. Ed. Orstom, Paris

Fenchel, T (1987). Ecology of protozoa. The biology of freeliving phagotrophic protists. Springer-Verlag, Berlin

Finlay, B. J., Clarke, K. J., Cowling, A. J., Hindle, R. M., Rogerson, A. (1988). On the abundance and distribution of protozoa and their food in a productive freshwater pond. Eur. J. Protistol. 23: 205-217

Foissner, W. (1988). Taxonomic and nomenclatural revision of Sladecek's list of ciliates (Protozoa: Ciliophora) as indicators of water quality. Hydrobiologia 166: 1-64

Fowler, S. W., Knauer, A. (1986). Role of large particles in the transport of elements and organic compounds through the oceanic water column. Prog. Oceanogr. 16: 147-194

Frost, B. W. (1987). Grazing control of phytoplankton stock in the open subarctic Pacific Ocean: a model assessing the role of mesozooplankton, particularly the large calanoid copepods Neocalanus spp. Mar. Ecol. Prog. Ser. 39: 49-68

Garrison, D. L., Buck, K. R. (1989). Protozooplankton in the Weddell Sea, Antarctica: abundance and distribution in the ice-edge zone. Polar Biol. 9: 341-351

Geary, R. C. (1954). The contiguity ratio and statistical mapping. The Incorporated Statistician 5: 115-145

Genin, A., Boehlert, G. W. (1985). Dynamics of temperature and chlorophyll structures above a seamount: an oceanic experiment. J. mar. Res. 43: 907-924

Genin, A., Haury, L., Greenblatt, P. (1988). Interactions of migrating zooplankton with shallow topography: predation by rockfishes and intensification of patchiness. Deep Sea Res. 35: 151-175

Grigg, R. W., Malahoff, A., Chave, E. H., Landal, J. (1987). Seamount benthic ecology and potential environmental impact from manganese crust mining in Hawaii. In: Keating, B. H., Fryer, P., Batiza, R., Boehlert, G. W (eds.) Seamounts, islands and atolls. Geophysical Monograph 43. American Geophysical Union, Washington, DC, p. 379-390

Grolière, C. A. (1980). Morphologie et stomatogénèse chez deux ciliés Scuticociliatida des genres Philasterides Kahl, 1926 et Cyclidium O. F. Müller, 1786. Acta Protozool. 19: 195-206

Hargraves, P. E. (1981). Seasonal variations of tintinnids (Ciliophora: Oligotrichida) in Narragansett Bay, Rhode Island, USA. J. Plankton Res. 13: 81-91

Holm-Hansen, O., Lorenzen, C. J., Holmes, R. W., Strickland, J. D. H. (1965). Fluorometric determination of chlorophyll. J. Cons. int. Explor. Mer 30: 3-15

Huppert, H. E., Bryan, K. (1976). Topographically generated eddies. Deep Sea Res. 23: 655-679

Jonsson, P. R. (1987). Photosynthetic assimilation of inorganic carbon in marine oligotrich ciliates (Ciliophora, Oligotrichina). Mar. microb. Fd Webs 2: 55-68

Joyce, T M. (1987). Hydrographic sections across the Kuroshio extension at $165^{\circ} \mathrm{E}$ and $175^{\circ} \mathrm{W}$ Deep Sea Res. 34: 1331-1352

Kaneko, A., Honji, H., Kawatate, K., Mizuno, S., Masuda, A., Miita, T. (1986). A note on internal wavetrains and the associated undulation of the sea surface observed upstream of seamount. J. oceanogr. Soc. Japan 42: 75-82

Lampitt, R. S. (1985). Evidence for the seasonal deposition of detritus to the deep-sea floor and its subsequent resuspension. Deep Sea Res. 32: 885-897

Laval-Peuto, M., Febvre, M. (1986). On plastid symbiosis in Tontonia appendiculariformis (Ciliophora, Oligotrichina). Biosystems 19: 137-158

Laval-Peuto, M., Salvano, P., Gayol, P., Greuet, C. (1986). 
Mixotrophy in marine planktonic ciliates: ultrastructural study of Tontonia appendiculariformis (Ciliophora, oligotrichina). Mar microb. Fd Webs 1. 81-104

Legendre, L., Legendre, P. (1984). Écologie numérique, 2e éd. Tome 2: La structure des données écologiques. Collect. Écol. 13. Masson, Paris

Legendre, P., Troussellier, M. (1988). Aquatic heterotrophic bacteria: modeling in the presence of spatial autocorrelation. Limnol. Oceanogr. 33: 1055-1067

Lessard, E. J. (1991). The trophic role of heterotrophic dinoflagellates in diverse marine environments. Mar. microb. Fd Webs 5: 49-58

Lilliefors, H. W (1967). The Kolmogorov-Smimov test for normality with mean and variance unknown. J. Am. stat. Ass. 62: $399-402$

Lopukhin, A. S. (1986). Distribution of ATP concentration above seamounts in the Atlantic Ocean. Oceanology 26 361-365

Marshall, S. M. (1969). Protozoa. Order: Tintinnida. In: Fraser, J. H. Hansen, V. Kr. (eds.) Fiches d'identification du zooplancton. Cons. Perm. int. explor. Mer., Charlottenlund, Denmark, sheets $117-127$

McManus, G. B., Fuhrman, J. A. (1986). Photosynthetic pigments in the ciliate Laboea strobila from Long Island Sound, USA. J. Plankton Res. 8: 317-327

Moran, P. A. P. (1950). Notes on continuous stochastic phenomena. Biometrika 37-17-23

Mysak, L. A., Magaard, L. (1983). Rossby wave driven Eulerian mean flows along nonzonal barriers, with application of the Hawailan Ridge. J. phys. Oceanogr 13: 1716-1725

Ohman, M. D., Snyder, R. A. (1991). Growth kinetics of the omnivorous ciliate Strombidium sp. Limnol. Oceanogr. 36 922-935

Pace, M. L., Orcutt, J. D. (1981). The relative importance of protozoans, rotifers, and crustaceans in a freshwater zooplankton community. Limnol. Oceanogr. 26: 822-830

Patzert, W. C. (1969). Eddies in Hawaiian waters. Rep. 69-8. Hawaiian Inst. Geophys, Honolulu

Platt, I., Dickie, L. M., Trites, R. W (1970). Spatial heterogeneity of phytoplankton in a near-shore environment. J. Fish. Res. Bd Can. 27: 1453-1473

Porter, K. G., Pace, M. L., Battey, J. F. (1979). Ciliated protozoa as links in freshwater planktonic food chains. Nature 277: 563-565

Pratt, J R., Cairns, J. J. (1985). Functional groups in the protozoa: role in differing ecosystems. J. Protozool. 32: 415-423

Putt, M., Stoecker, D. K. (1989). An experimentally determined carbon:volume ratio for marine oligotrichous ciliates from estuarine and coastal water Limnol. Oceanogr 34: 1097-1103

Rassoulzadegan, F., Laval-Peuto, M., Sheldon, R. W (1988). Partitioning of the food ration of marine ciliates between pico- and nanoplankton. Hydrobiologia 159: 75-88

Roden, G. I. (1987). Effect of seamounts and seamount chains on ocean circulation and thermohaline structure. In: Keating. B. H., Fryer, P., Batiza, R., Boehlert, G. W. (eds.) Seamounts, islands and atolls. Geophysical Monograph 43. American Geophysical Union, Washington, DC, p. 335-354

Roden, G. I., Taft, B. A. (1985). Effect of the Emperor Seamounts on the mesoscale thermohaline structure during the summer of 1982. J. phys. geophys. Res. 90: 839-855

Royer, T C. (1978). Ocean eddies generated by seamounts in the North Pacific. Science 199: 1063-1064

Sancetta, C., Villareal, T., Falkowski, P. (1991). Massive fluxes of rhizosolenid diatoms: A common occurrence? Limnol. Oceanogr. 36: 1452-1457
Sanders, R. W. (1987). Tintinnids and other microzooplankton - seasonal distributions and relationships to resources and hydrography in a Maine estuary. J. Plankton Res. 9: 65-77

Sherr, B. F., Sherr, E. B. (1984). Role of heterotrophic protozoa in carbon and energy flow in aquatic ecosystems. In: Klug, M. J., Reddy, C. A. (eds.) Current perspectives in microbial ecology. American Society for Microbıology, Washington, DC, p. $412-423$

Sime-Ngando, T., Grolière, C. A. (1991). Quantitative effects of fixatives on the storage of freshwater planktonic ciliates. Arch. Protistenk. 140: 109-120

Sime-Ngando, T., Hartmann, H. J. (1991). Short-term variations of the abundance and biomass of planktonic ciliates in a eutrophic lake. Eur. J. Protistol. 27: 249-263

Sime-Ngando, T., Hartmann, H. J., Grolière, C. A. (1990). Rapid quantification of planktonic ciliates: comparison of improved live counting with other methods. Appl. environ. Microbiol. 56: 2234-2242

Small, E. B., Lynn, D. H. (1985). Phylum Ciliophora Doflein, 1901. In: Lee, J. J., Hufner, S. H., Bovee, E. C. (eds.) Illustrated guide to the Protozoa. Society of Protozoologists, Lawrence, KS, p. 393-575

Smetacek, V (1981). The annual cycle of protozooplankton in the Kiel Bight. Mar. Biol. 63: 1-11

Smith, D. K., Jordan, T H. (1988). Seamount statistics in the Pacific Ocean. J. geophys. Res. 93: 2899-2919

Sokal, R. R. (1979). Ecological parameters inferred from spatial correlograms. In: Patil, G. P., Rosenzweig, M. L. (eds.) Contemporary quantitative ecology and related ecometrics. Stat. Ecol. Ser. Vol. 12. Int. Co-op. Publ. House, Fairland, p. 167-196

Sokal, R. R., Oden, N. L. (1978). Spatial autocorrelation in biology. 1 Methodology. Biol. J. Linnean Soc. Lond. 10: $199-228$

Sokal, R. R., Rohlf, F. J. (1981). Biometry: the principles and practice of statistics in biological research, 2nd edn. W. H. Freeman and Co., San Francisco

Stoecker, D. K., Egloff, D. A. (1987). Predation by Acartia tonsa Dana on planktonic ciliates and rotifers. J. exp. mar Biol. Ecol. 110: 53-68

Stoecker, D. K., Michaels, A. E., Davis, L. H. (1987). Large proportion of marine planktonic ciliates found to contain functional chloroplasts. Nature 326: 790-792

Stoecker, D. K., Silver, M. W., Michaels, A. E., Davis, L. H. (1988). Obligate mixotrophy in Laboea strobila, a ciliate which retains chloroplasts. Mar. Biol. 99: 415-423

Stoecker, D. K., Taniguchi, A., Michaels, A. E. (1989). Abundance of autotrophic, mixotrophic and heterotrophic planktonic ciliates in shelf and slope water Mar Ecol. Prog. Ser 50: 241-254

Strom, S. (1990). Some aspects of the ecology of herbivorous protozoa of the open subarctic Pacific Ocean. Ph.D. thesis, Univ. of Washington

Strom, S. L. (1991). Growth and grazing rates of the herbivorous dinoflagellate Gymnodinium sp. from the open subarctic Paclfic Ocean. Mar. Ecol. Prog Ser. 78: 103-113

Takahashi, M., Hoskins, K. D. (1978). Winter condition of marine plankton populations in Saanich Inlet, $B$. C., Canada, II. Micro-zooplankton. J. exp. mar. Biol. 32: 27-37

Taniguch1, A. (1984). Microzooplankton biomass in the arctic and subarctic Pacific Ocean in summer Mem. nat. Inst. polar Res., Tokyo (Spec. Issue) 32: 63-76

Tuffrau, M. (1967). Perfectionnements et pratique de la technique d'imprégnation au protargol des infusoires ciliés. Protistologica 3: 91-98

Tumantseva, N. I. (1982). Biomass and productive characteristic of protozoan plankton in subantarctic and antarctic 
waters of the southwestern Pacific. Oceanology 22: $604-608$

Uchida, R. N., Tagami, D. L. (1984). Groundfish fisheries and research in the vicinity of seamounts in the North Pacific Ocean. Mar. Fish. Rev. 46: 1-17

Vastano, A. C., Hagan, D. E., McNally, G. J. (1985). Lagrangian observations of surface circulation at the Emperor seamount chain. J. geophys. Res. 90: 3325-3331

Venrick, E. L. (1979). The lateral extent and characteristics of the North Pacific central environment at $35^{\circ} \mathrm{N}$. Deep Sea Res. 26: 1153-1178

Venrick, E. L. (1991). Mid-ocean ridges and their influence on

This article was submitted to the editor the large-scale patterns of chlorophyll and production in the North Pacific. Deep Sea Res. 38: S83-S102

Venrick, E. L., Cummings, S. L., Kemper, C. A. (1987). Picoplankton and the resulting bias in chlorophyll retained by traditional glass-fiber filters. Deep Sea Res. 34: 1951-1956

White, W B., Walker, A. E. (1985). The influence of the Hawaiian Archipelago upon the wind-driven subtropical gyre in the Western North Pacific. J. geophys. Res. 90: $7061-7074$

Yentsch, C. S., Menzel, D. W. (1963). A method for the determination of phytoplankton chlorophyll and phaeophytin by fluorescence. Deep Sea Res. 10: 221-231

Manuscript first received: June 16, 1992

Revised version accepted: October 7, 1992 